\title{
Phytoplankton and pigment studies in the Bay of Biscay and English Channel
}

\author{
Denise Smythe-Wright*, Aaron Daniel, Stephen Boswell, Diane Purcell, Mark Hartman, \\ Susan Hartman, David Hydes \\ National Oceanography Centre, Southampton SO14 3ZH, UK
}

\section{A R T I C L E I N F O}

Available online 16 January 2014

Keywords:

Algal pigments

Phytoplankton

Bay of Biscay

Ship of opportunity

\begin{abstract}
A B S T R A C T
During the final year (2010) of the MV Pride of Bilbao (PoB) ferry operation between Portsmouth (UK) and Bilbao (Spain) a comprehensive phytoplankton data set was collected based on pigments and taxonomy measurements. The work was in support of the EU project ProTool (http://www.protool-project.eu) that aimed to develop an automated system for measuring primary productivity from ships of opportunity. Not unexpectedly, the biological patterns relate to the hydrographic conditions and in general, pigment distributions are indicative of the taxonomy. A predominately diatom bloom was observed in the Bay of Biscay in April, with a mixed population of diatoms, dinoflagellates and coccolithophores throughout the spring and summer, and a very distinctive bloom, which contained a large proportion of the dinoflagellate Karenia Mikimotoi, to the stratified side of the Ushant Front in mid-July.
\end{abstract}

Crown Copyright (c) 2014 Published by Elsevier Ltd. All rights reserved.

\section{Introduction}

Marine phytoplankton are responsible for over half of our planet's primary production. Not only do they form the base of the marine food chain (Fenchel, 1988), but also they provide over $60 \%$ of our planet's oxygen (Roach, 2004), regulate the increasing manmade atmospheric carbon dioxide (Bates et al., 2012) and provide a route for its export from the atmosphere to the deep ocean (Yool et al., 2007). Phytoplankton uptake and export to the ocean's interior as organic matter is known as the 'biological pump'. The mechanism lowers the partial pressure of carbon dioxide in the upper waters and facilitates the diffusive drawdown of atmospheric carbon dioxide. Consequently phytoplanktons are fundamental to the health of our planet, but not necessarily en mass; species diversity is also important. For example, large chain forming diatoms are thought to contribute the most to carbon export because of their large size and the density of their opaline shells (Karl et al., 2012). On the other hand, the precipitation of calcium carbonate by calcifying organisms (e.g. coccolithophores) increases the partial pressure of carbon dioxide and promotes outgassing from the ocean to the atmosphere, a process known as the carbonate or alkalinity pump, that plays a vital role in maintaining equilibrium in ocean carbon chemistry (Elderfield, 2002). Furthermore, there are numerous species of micro-algae

\footnotetext{
*Corresponding author. Tel.: +44238059 6440; fax: +442380596247.

E-mail address: dsw@noc.ac.uk (D. Smythe-Wright).
}

(e.g. dinoflagellates) that are toxic both to marine and human life (Moestrup et al., 2009).

Multiple phytoplankton species appear in marine waters throughout the spring and summer with their relative abundances at various stages of the seasonal cycle depending on localised distributions of the resources required for marine plant growth, in particular, light and the availability of inorganic nutrients. In general, throughout the oceans, diatoms are the first to bloom from March-May due to their tolerance of the turbulent, low-light, spring conditions which occur early in the season. They provide the food source for the many planktonic animals and fish that specifically time the laying of their eggs to match the onset of the bloom. Dinoflagellate blooms often follow diatom proliferations and this has been demonstrated in the western English Channel (Garcia-Soto and Pingree, 2009; Pingree et al., 1975; Pingree et al., 1977). The former mobile phytoplankton are able to "swim" small distances, with the aid of flagella, taking advantage of vertically segregated food sources. Some dinoflagellates provide a food source for planktonic animals during the summer, while others contribute to harmful algal blooms (HABs) that deter grazing and lead to mortality (Ayres and Cullum, 1978; Ayres et al., 1982; Turner et al., 1987; Davidson et al., 2009; Silke et al., 2005). Consequently, any changes in the balance between, for example, diatoms to dinoflagellates may have major effects on biodiversity at higher trophic levels. Furthermore, any alteration in the abundance of calcifying organisms e.g. coccolithophores, may impact the oceans ability to take up carbon dioxide. 
The sensitivity of phytoplankton growth to environmental factors (Behrenfeld et al., 2008) means that, within a particular geographic or climatic region, phytoplankton abundance varies at time scales ranging from a few days, to annual, decadal and millennial. This depends on local conditions such as storms and tides, year-to-year differences in prevailing conditions, climatic oscillations and climate change.

Climate prediction models tell us that phytoplankton communities are liable to change over the next century and could substantially decline (Sarmiento et al., 2004). There is some debate as to whether this is actually happening (Boyce et al., 2010; Mc Quatters-Gollop et al., 2011). Nevertheless, there is clear evidence that as northern waters warm, due to increasing sea surface temperature, there has been $\mathrm{a}>10^{\circ}$ latitude northward shift in plankton blooms with increasing biomass over the past 50 years (Beaugrand and Reid, 2003; Beaugrand et al., 2008; MCCIP, 2010). In addition, the seasonal timing of plankton production has altered with some species appearing up to 4-6 weeks earlier than 20 years ago. The most pronounced effect of an abrupt ecosystem shift occurred in the later 1990 s near the $9-10{ }^{\circ} \mathrm{C}$ sea surface temperature isotherm. This is a critical boundary between 'warm' and 'cold' water and as water is warming this boundary is moving northwards. The effects of such regime shifts are important for predators. In general, tropical species are small and do not provide a food source for higher trophic levels. They are also considered to be less important in the draw-down of carbon because their small size makes them less likely to sink to depth. In contrast, the release of large amounts of cold, low-salinity water into the North Atlantic from melting Arctic ice sheets and glaciers has introduced the Pacific Ocean diatom Neodenticula seminae into the North Atlantic for the first time in 800,000 years (Reid et al., 2007). Although it only crossed over the Arctic Ocean a little over a decade ago, it has already spread into the North Atlantic region.

To understand long-term changes over and above the natural inter-annual variability it is vital to make, on a regular basis, comprehensive measurements that provide a firm footing for extrapolation and prediction. In addition, it is vital to have good, continuously updated, baseline knowledge of phytoplankton communities in shelf and coastal areas so that the effects of human pressures over and above environmental change can be teased out.

Since 2002, the National Oceanography Centre, in the UK has operated a Ferrybox system on the P\&O ferry MV Pride of Bilbao from Portsmouth (UK) - Bilbao (Spain) taking standard temperature, salinity, oxygen and fluorometer measurements. In 2010, this was augmented with the collection of samples for plant pigment analysis, backed up by samples for microscope counting of phytoplankton species and nutrient concentrations. This comprehensive set of measurements has enabled us to study phytoplankton distributions in the surface waters of the Bay of Biscay and the western English Channel and to compare them with other measurements made at a similar temporal and spatial resolution from the P\&O ferry in 2003 and 2004. A companion paper Hartman et al. (2013) provides an analysis of the nutrient supply in relation to the mixing in the Bay of Biscay. Measurements of Sea Surface Temperature, PAR irradiance, wind speed and turbulence and phytoplankton concentration for the years 1997-2007 along the same FerryBox line can found in Garcia-Soto and Pingree (2009).

\section{Area of study}

The Bay of Biscay (see Fig. 1) positioned on the edge of the NW European continental shelf is open to the Northeast Atlantic on its western edge and bounded by the land masses of Spain to the south and France to the east. To the north lies the shallow Celtic Sea $(<200 \mathrm{~m})$, whereas the central part of the Bay reaches depths

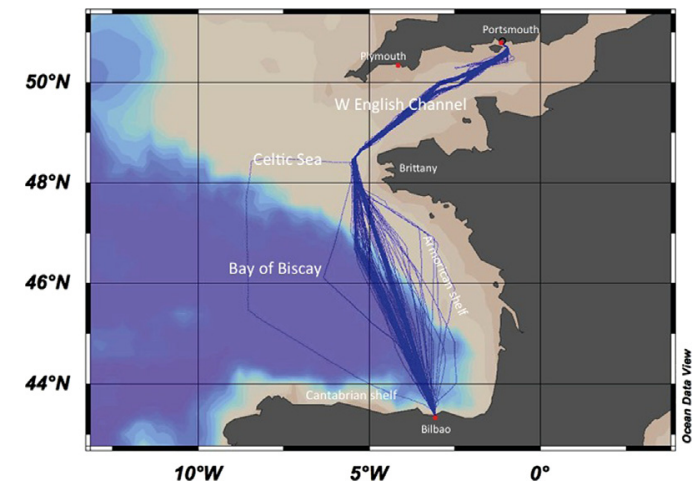

Fig. 1. The route of the $P \& O M V$ Pride of Bilbao in 2010. The results presented in this manuscript do not include the track to the extreme west of the area, which was necessary due to foul weather conditions.

in excess of $4000 \mathrm{~m}$. To the northeast lies the narrow English Channel that provides a route from the North Atlantic to the North Sea. The hydrography of the two regions and the parameters that influence them has been comprehensively discussed with wind and tide playing an important role. The large tidal currents and shallow water depth (30-70 m) of the central part of the English Channel and along the French coast, maintain a well-mixed water column throughout the year (Pingree and Griffiths, 1978). By comparison, much of the western English Channel and Celtic Sea has weaker tides and greater depth allowing a strong seasonal thermocline to develop during the summer months (Pingree, 1980) with a distinct frontal zone, the Ushant Front, at approximately $3.5^{\circ} \mathrm{W}-4.5^{\circ} \mathrm{W}$. To the south along the wide $(150-180 \mathrm{~km})$ shelf area south of the island of Ushant $\left(48.46^{\circ} \mathrm{N}, 5.1^{\circ} \mathrm{W}\right)$ the waters offshore are highly stratified in summer (Pingree and Griffiths, 1978). In addition, there are tidal frontal regions running along the coast from the Gironde to the Ras de Seine (Pingree et al., 1982) and the central part of the Bay of Biscay also becomes thermally stratified and oligotrophic in summer. Further south the narrow continental shelf $(\sim 12 \mathrm{~km})$ off northern Spain is often eutrophic (González et al., 2003). Both the Channel and the Bay of Biscay are subjected to fresh water input in the summer after the spring bloom in March/April (Garcia-Soto and Pingree, 2009), with the Seine being the main source to the English Channel (primarily the eastern Channel) and the combined estuaries of the Loire and Gironde spreading onto the Armorican Shelf. High discharges, particularly in spring, are known to cause salinity anomalies with distinct low salinity lenses $(<35.0$ ) off the Brittany coast (Puillat et al., 2004) which have been further studied and modelled in Laiz et al. (2014).

The $\mathrm{P} \& \mathrm{O}$ ferry route from the UK to Spain passed through both the English Channel and Bay of Biscay and so provided information across a number of hydrographic and biological areas over a variety of temporal and spatial conditions. The route was particularly advantageous in that it was operational all year round and had a repeat rate of 4 times per week on its twice weekly return journey between Portsmouth and Bilbao, thus enabling events such as storms, plankton blooms, salinity anomalies and the effects of stratification to be measured. However, the linear nature of the ferry track constrains the spatial resolution, which is a disadvantage for capturing the variable spatial distribution of summer phytoplankton blooms.

\section{Methodology}

Personnel travelled on the MV Pride of Bilbao at approximately monthly intervals between February and May and then at 


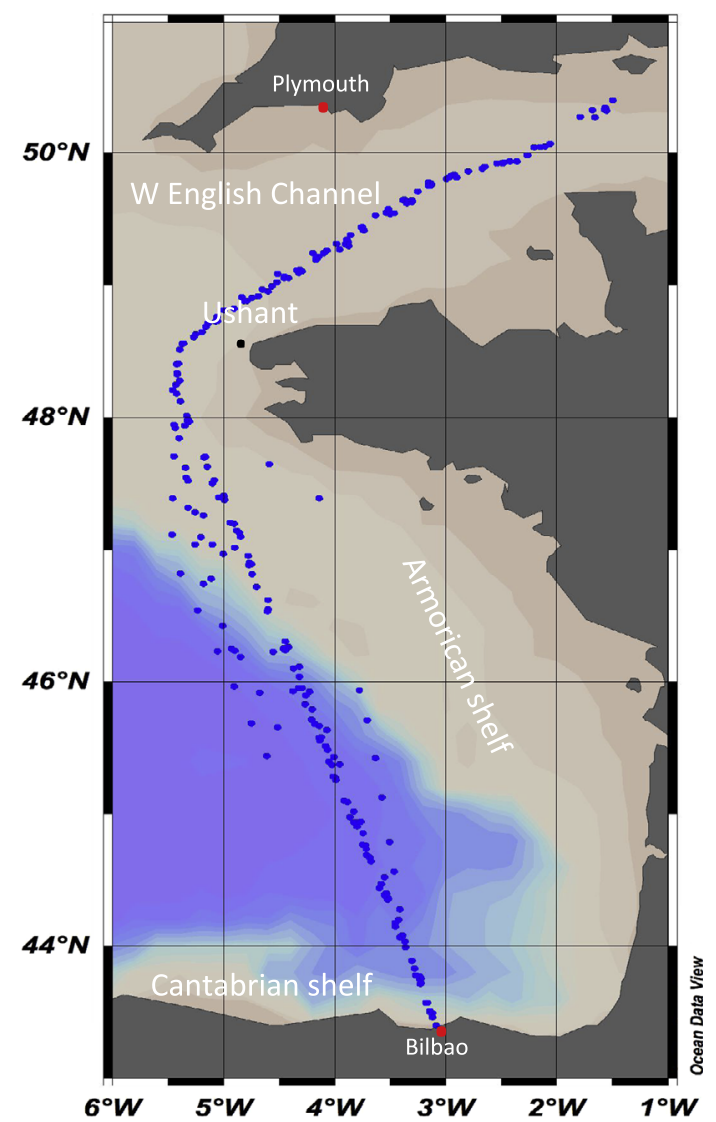

Fig. 2. Station positions during the manned crossings of the MV Pride of Bilbao ferry in 2010 .

approximately 2 week intervals between June and September. The tracks and sampling positions during the manned crossings are shown in Fig. 2. Over the 3-day transit period, personnel manually collected $5 \mathrm{~L}$ seawater samples every $2 \mathrm{~h}$ from the ship's seawater cooling supply, pumped from $5 \mathrm{~m}$ below the sea surface. This was the same seawater flow as that attached to the Ferrybox system (see below) and following collection the sample was processed as follows for the different measurements.

\subsection{Phytoplankton pigments}

Samples for pigment analysis were harvested by filtering $2 \mathrm{~L}$ of the bulk sample through Whatman GF/F filters. This was done in duplicate and the filter papers immediately placed in vials and stored in the on board $-80{ }^{\circ} \mathrm{C}$ freezer prior to transportation to NOC where they were again stored at $-80^{\circ} \mathrm{C}$ before analysis.

The pigments were subsequently extracted from each filter by placing the filter in the bottom of a $15 \mathrm{ml}$ centrifuge tube and totally immersing it with $3 \mathrm{ml}$ of $100 \%$ LC-MS grade methanol. The tube was then placed in a beaker of ice to prevent heating and sonicated for $30 \mathrm{~s}$ in order to break up the filter, being careful to keep the filter immersed in the liquid and not to smash it to a pulp. The tube was then placed in a refrigerator and left overnight $(\sim 16 \mathrm{~h})$ for the extraction to complete. Following the extraction period the tube was centrifuged at $4000 \mathrm{rpm}$ for $10 \mathrm{~min}$ and $1 \mathrm{ml}$ of the supernatant transferred to a smaller $1.5 \mathrm{ml}$ vial, which was then ultra-centrifuged at $14,000 \mathrm{rpm}$ for $10 \mathrm{~min}$. $200 \mu \mathrm{l}$ of this supernatant was then transferred to an amber vial, closed with a septum cap and placed in the sample tray of an Agilent 1200 series High Performance Liquid Chromatograph (HPLC) fitted with an LC/Diode array and attached to an Agilent 6410 triple quad MS.
The HPLC method employed was similar to that first described by Gibb et al. (2001) with a few modifications, primarily the use of a Hypersil C8 $(10 \times 0.3 \mathrm{~cm})$ column and two solvents: $70 \%$ methanol/30\% $1 \mathrm{M}$ ammonium acetate buffer and 100\% methanol. The pigments were identified from their retention time and diode array peak response; mass spectrographs were used as confirmation if necessary. All data were compared with those of pure standards obtained from DHI, Denmark. The pigments measured were chlorophyll-a, chlorophyll-c2 and -c3, peridinin, 19'-butanoyloxyfucoxanthin, fucoxanthin, 19'-hexanoyloxyfucoxanthin, diadinoxanthin, violaxanthin, prasinoxanthin, lutein, alloxanthin, zeaxanthin, total carotene, total chlorophyll b and divinyl chlorophyll-a. Pigment concentrations were calculated using the following equation:

Concentration $\left(\mu \mathrm{g} \mathrm{m}^{-3}\right)=\frac{P A \times V E \times 1000}{R F \times V I \times V F \times 0.5}$

where $P A$ is the peak area (arbitrary units), $V E$ is the volume ( $\mathrm{ml}$ ) of $100 \%$ methanol used for extraction, $R F$ is the response factor calculated from instrument calibration (PA/concentration in $\mathrm{ng}), \mathrm{VI}$ is the injected sample volume $(\mu \mathrm{l})$ for analysis, and VF is the volume (L) of water filtration through the GF/F filter. Contour plots were produced with Ocean Data View software with DIVA gridding (Schlitzer, 2008).

\subsection{Microscope counts}

Samples for microscope counting were preserved on the ship by filling $100 \mathrm{ml}$ amber glass bottles in which $0.4 \mathrm{ml}$ of $2 \%$ acidic Lugol's solution had already been added. These were stored in the dark at $4{ }^{\circ} \mathrm{C}$ prior to a sub-sample being settled in a $50 \mathrm{ml}$ settling chamber (Duncan and Associates, UK) for $24 \mathrm{~h}$ and subsequently examined using an LEICA DM IRB inverted microscope.

Taxonomic counting was carried out using the methodology of Hasle (1978). Large and numerically rare taxa were counted during full examination of the settling chamber ( $x 100$ magnification), while small $(<50 \mu \mathrm{m})$ and numerically dominant taxa were counted on $1-2$ transects of the chamber $(x 100$ or $\times 200$ magnification) or from cumulative counts of 5-10 fields of view ( $\times 400$ magnification). Diatoms and dinoflagellates were identified to genera or species following Tomas (1997).

\subsection{Ferrybox and nutrient data}

Details of the P\&O Ferrybox system are given in Hydes et al. (2003) and Kelly-Gerreyn et al. (2006). Briefly, the ship's cooling water supply was directed to flow over a series of in situ sensors at a rate of $15-20 \mathrm{~L} \mathrm{~min}^{-1}$ and data were collected at $30 \mathrm{~s}$ intervals (see Fig. 1 for ship's track). Aanderra sensors were employed to

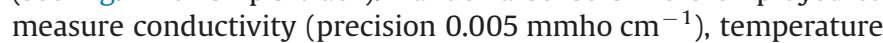
(precision $0.003{ }^{\circ} \mathrm{C}$ ) and dissolved oxygen and a Turner C3 sensor to measure chlorophyll-fluorescence (precision $0.025 \pm 0.01 \mathrm{mg}$

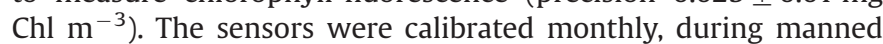
crossings, with samples collected from the same seawater supply as that used for the biological samples described above and measured for salinity (Autosal salinometer), dissolved oxygen (Winkler titration) and chlorophyll-a (HPLC). In addition, monthly samples were collected for the analysis of total oxidised nitrogen, (nitrate + nitrite, hereafter referred to as nitrate), silicate and phosphate and analysed by the standard method of Grasshoff (1983).

\section{Results}

The results presented here do not include the extreme westerly track shown in Fig. 1 (this was necessary due to foul weather 
conditions), but do include the two isolated points to the east of the main route off the southern Brittany coast shown in Fig. 2. Each ferry transect was approximately $1000 \mathrm{~km}$ and the repeat journey took on average $70 \mathrm{~h}$ resulting in a repeat sampling rate of between $4 \mathrm{~h}$ and 3 days depending on location. Traditionally, chlorophyll-a has been used as a marker pigment for estimating phytoplankton biomass (Jeffrey and Mantoura, 1997). More recently, with the development of HPLC techniques, other pigments that have strong chemotaxonomic associations have been used as markers of phytoplankton community composition. Since HPLC analysis avoids long hours of taxonomic counting we have used pigment distributions backed up by confirmatory counting in this study. For example, fucoxanthin is the main photosynthetic pigment for diatoms (Wright and Jeffrey, 1987) although it is also found in many strains of haptophyta (Zapta et al., 2004) and is known to be the main pigment of toxic dinoflagellates. Peridinin is the primary photosynthetic pigment in autotrophic dinoflagellates (Gibb et al., 2001), whereas 19'-hexanoyloxyfucoxanthin is the marker for prymnesiophytes including coccolithophores and Phaeocyctis ssp. (Bjørnland and Liaaen-Jensen, 1989) and 19'-butanoyloxyfucoxanthin for chrysophytes (Barlow et al., 1993). In addition, phytoplankton have a number of accessory photoprotective pigments such as diadinoxanthin, which is found in a number of algal divisions and classes and zeaxanthin, which is primarily associated with cyanophytes and prochlorophytes (Jeffrey and Mantoura, 1997). Throughout the text the term day refers to year day.

\subsection{Temperature and salinity}

The temperature, salinity, fluorescence and oxygen anomaly (actual concentration - expected concentration in equilibrium with atmosphere) data from the on board sensors, binned to 5 min intervals, are shown in Fig. 3. Fig. 3(a) clearly shows seasonal and geographical differences in temperature, with cool temperatures in the Channel in the early spring $\left(\sim 6^{\circ} \mathrm{C}\right)$ and warm waters $\left(\max 23.5^{\circ} \mathrm{C}\right.$ ) in the southern Bay of Biscay in mid-late summer. Similar seasonal and geographical differences are also reported in previous studies along the same ferry line (Hartman et al., 2013; Garcia-Soto and Pingree, 2009). What is clear is the variability between $48^{\circ} \mathrm{N}$ and $50^{\circ} \mathrm{N}$ in the SW Approaches reflects the tidal mixing and weaker thermocline development in this region (Pingree, 1975). Salinity (see Fig. 3b) also shows some variability, this time south of $48^{\circ} \mathrm{N}$, with patches of water lower than 34.5 PSU off the southern Brittany coast in the spring and some anomalies $<35.25$ PSU south of $46^{\circ} \mathrm{N}$ in mid-summer. The coastal effects of the UK and Northern Spain, with salinities lower than 34.0 PSU, are more clearly visible from the discrete sample data shown in Fig. 4a. The very low salinity patch on Day 103 is from a sampling point very close to the Brittany coast at $47.39^{\circ} \mathrm{N}$, $4.14^{\circ} \mathrm{W}$.

\subsection{Fluorescence and oxygen}

Data from the fluorescence sensor shown in Fig. 3(c) indicate that phytoplankton biomass was also very patchy with a bloom in the central Bay of Biscay in April/May (Day 100-135), but relatively little after that. To the north, patches of activity were more common with a high spot on Day 196 (15th July) at $49.5^{\circ} \mathrm{N}$ in the central English Channel. These findings are in agreement with Garcia-Soto and Pingree (1998) and Garcia-Soto and Pingree (2009) who showed a timing of the spring bloom for the Central Bay of Biscay around Day 120. They also reported summer blooms in the western English Channel during mid-July-September with a high inter-annual variability during the years 2000, 2002, 2003, 2004 and 2006.
The higher levels of fluorescence are mirrored in the oxygen data. Fig. 3(d) shows that the oxygen values were up to $60 \mu \mathrm{mol} \mathrm{kg}^{-1}$ during the early spring bloom and in excess of $100 \mu \mathrm{mol} \mathrm{kg}^{-1}$ above saturation during the bloom on Day 196 suggesting high productivity at these times. In general there is good correlation between the fluorescence and oxygen anomaly data in the central English Channel area throughout the year.

\subsection{Nutrients}

Together with salinity, Fig. 4 shows the distribution of nutrients from discrete samples collected along the route in 2010. Generally speaking nutrients are high in the spring, with the Biscay region becoming close to oligotrophic by early summer. Spring concentrations (up to Day 75) range from $1.5-7.0 \mu \mathrm{mol} \mathrm{kg}^{-1}$ silicate, $2.5-12.5 \mu \mathrm{mol} \mathrm{kg} \mathrm{kg}^{-1}$ nitrate and $0.2-0.7 \mu \mathrm{mol} \mathrm{kg}{ }^{-1}$ phosphate, declining rapidly in early April ( $>$ Day 90), with just a couple of high spots around $46^{\circ} \mathrm{N}$ and $49^{\circ} \mathrm{N}$. Particularly low concentrations of silicate occur between $47^{\circ} \mathrm{N}$ and $48^{\circ} \mathrm{N}$ with silicate values dropping to $<0.1$ off the southern Brittany coast $\left(\sim 47.5^{\circ} \mathrm{N}\right)$ and in the central parts of the English Channel $\left(\sim 50^{\circ} \mathrm{N}\right)$.

Similarly nitrate and phosphate follow this pattern, but what is particularly interesting is the low nitrate values seen on Day 196 and on Day 232 in the western English Channel. With these exceptions, nutrients in this area of the English Channel (between $48^{\circ} \mathrm{N}$ and $50^{\circ} \mathrm{N}$ ) remain relatively high (> $1.5 \mu \mathrm{mol} \mathrm{kg}{ }^{-1}$ silicate, $>2.5 \mu \mathrm{mol} \mathrm{kg}^{-1}$ nitrate and $>0.2 \mu \mathrm{mol} \mathrm{kg}-1$ phosphate) all year (see Fig. 4) and there is a relationship, albeit relatively weak, with lower salinity waters. Similar distributions for other years are reported in Hartman et al. (2013) and may be compared to Pingree et al. (1977) and Pingree and Pennycuick (1975).

\subsection{Pigments and species}

The distribution of the dominant pigments in both the Bay of Biscay and the English Channel is shown in Fig. 5 in a south to north orientation. [Note that scaling has been chosen to show overall patterns and that maximum concentrations are often greater than the values shown on the scale].

It is clear from the data that prior to Day 100 phytoplankton biomass is low with chlorophyll-a concentrations $<0.25 \mu \mathrm{g} \mathrm{L}^{-1}$. The situation changes on Day 104 when an increase in both chlorophyll-a (to $\sim 1.56 \mu \mathrm{g} \mathrm{L}^{-1}$ ) and fucoxanthin (to $\sim 0.33 \mu \mathrm{g} \mathrm{L}^{-1}$ ) in the central Bay of Biscay and English Channel (see Fig. 5a and b ) occurs. A second high spot in these two pigments is also seen in the Channel on Day 169 when fucoxanthin levels reach $0.36 \mu \mathrm{g} \mathrm{L}^{-1}$. Except at $45^{\circ} \mathrm{N}$, where there is no diatom data to corroborate, these distributions are mirrored, to a large extent, by the distribution of diatoms, concentrations of which reach $>0.2 \times 10^{6}$ cells L $^{-1}$ (see Fig. 5c). However, diatoms cannot account for the very high levels of chlorophyll-a $\left(13.6 \mu \mathrm{g} \mathrm{L}^{-1}\right)$ and fucoxanthin $\left(2.6 \mu \mathrm{g} \mathrm{L}^{-1}\right)$ seen on Day 196. In this case there seems to be a better relationship with the distribution of dinoflagellates $\left(0.8 \times 10^{6}\right.$ cells $\left.\mathrm{L}^{-1}\right)$ as shown in Fig. $5 \mathrm{~d}$. What is curious is that, at first sight, the distribution of the dinoflagellates is not reflected by the distribution of their marker pigment peridinin (see Fig. 5e). Peridinin concentrations are low $\left(<0.06 \mu \mathrm{g} \mathrm{L}^{-1}\right)$ throughout the entire region throughout all seasons except for three high spots in the English Channel on Days 169, 196 and 217 when concentrations reach up to $0.14 \mu \mathrm{g} \mathrm{L}^{-1}$. There is however some correlation with the pigment 19'-hexanoxyfucoxanthin (see Fig. 5f) with its concentration reaching over $0.3 \mu \mathrm{g} \mathrm{L}^{-1}$ in the English Channel on Day 196. Normally, 19'-hexanoxyfucoxanthin denotes coccolithophores and this is the case on Day 145, when their concentration reaches $\sim 3000$ cells L ${ }^{-1}$ (see Fig. $5 \mathrm{~g}$ ). Further north at $49^{\circ} \mathrm{N}$ the $19^{\prime}$-hexanoxyfucoxanthin probably arises from 
(a)

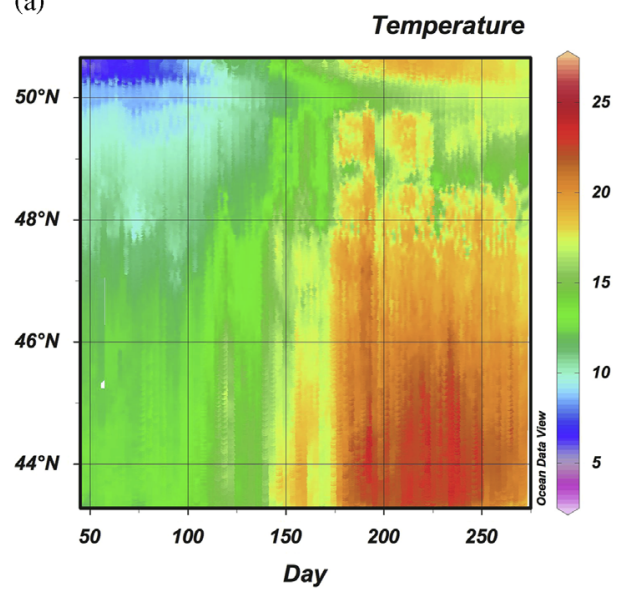

(c)

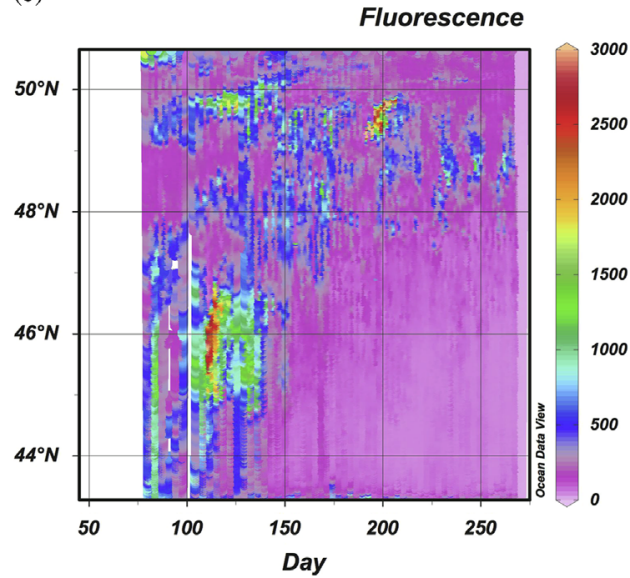

(b)

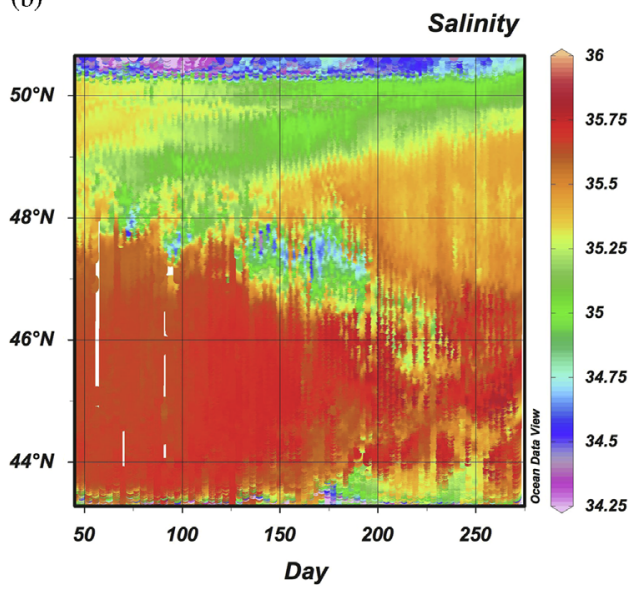

(d)

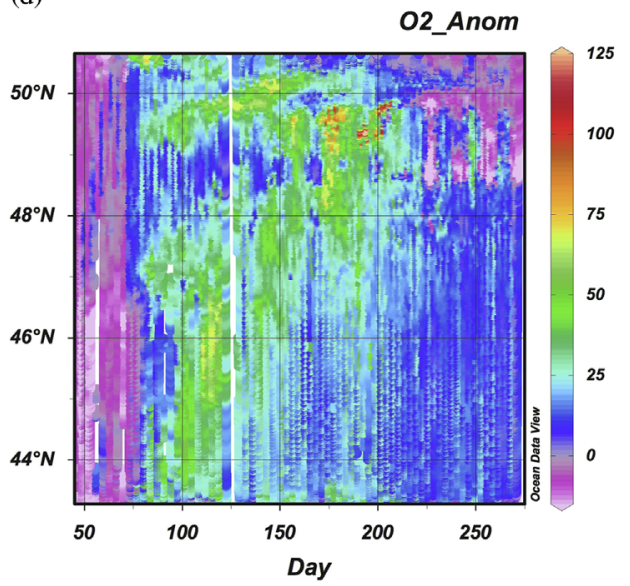

Fig. 3. Data from the Ferrybox system showing (a) temperature $\left({ }^{\circ} \mathrm{C}\right)$, (b) salinity (PSU), (c) fluorescence $\left(\mathrm{mg} \mathrm{Chl} \mathrm{m}^{-3}\right)$ and $(\mathrm{d})$ oxygen anomaly $\left(\mu \mathrm{M}\right.$ kg $\left.{ }^{-1}\right)$.

the mixed population of both coccolithophores and dinoflagellates. Other pigments of note are 19'-butanoxyfucoxanthin, which has high concentrations (up to $0.4 \mu \mathrm{g} \mathrm{L}^{-1}$ ) in the central English Channel in late summer and zeaxanthin, which becomes significant in the Bay of Biscay after the other pigments have declined, but also has high levels $\left(\sim 0.8 \mu \mathrm{g} \mathrm{L}^{-1}\right)$ in the western Channel on Day 196. These two pigments would suggest the presence of crysophytes and prochlorophytes respectively.

\section{Discussion}

The results through 2010 clearly show that phytoplankton blooms in the Bay of Biscay and English Channel are very patchy. While there is a hint of activity in the fluorescence data (Fig. 3) around Day 75 (March 15th) in the Bay of Biscay and off the coast of Portsmouth, the main blooms seem to appear after Day 100 (April 10th) and continue through to late May in the Bay of Biscay and well into the summer in the English Channel in 2010. Within this overall pattern specific species show temporal and spatial variations. A previous analysis of spring bloom timing and northward progression during 10 years along the same ferry line is given in Garcia-Soto and Pingree (2009).

\subsection{Diatoms}

Our measurements on Day 104 (14th April) suggest that the high biomass centred on $46^{\circ} \mathrm{N}$ in the fluorescence data (see Fig. 3 ) on Day 105 is associated with a diatom bloom. The species counts from $46.9^{\circ} \mathrm{N}, 4.77^{\circ} \mathrm{W}$ on this day show that the diatom Nitzschia sp. ( $\sim 21,000$ cells $\left.L^{-1}\right)$ is the most dominant, with lesser distributions of Navicula and Coscinodiscus $\left(\sim 7000\right.$ cells $\left.\mathrm{L}^{-1}\right)$. Diatoms are more prevalent on Day 169 in the western English Channel (2.52 $\mu \mathrm{g} \mathrm{L}^{-1}$ chlorophyll-a); here the bloom is also dominated by Nitzschia sp $\left(\sim 163,000\right.$ cells $\left.\mathrm{L}^{-1}\right)$ with a high proportion of Leptocylindrus danicus $\left(\sim 118,000\right.$ cells $\left.\mathrm{L}^{-1}\right)$. The onset of the bloom appears to coincide with temperatures reaching $12{ }^{\circ} \mathrm{C}$ and while the fluorescence data suggest a north-south progression in timing in the Bay of Biscay as was previously suggested by Garcia-Soto and Pingree (1998, 2009) and by Beaugrand et al. (2000), the lack of resolution in the $2010 \mathrm{PoB}$ pigment and species data set cannot resolve this.

Following the bloom silicate concentrations are depleted within the Bay of Biscay, suggesting that this is the limiting factor. This is not the case in the English Channel as small patches of diatoms do continue to appear off the Brittany coast and in the Channel throughout the summer. This is most likely due to the tidal mixing off Brittany and the northern French coast maintaining some presence of silicate from mixed waters (Pingree and Griffiths, 1978).

Comparison with monthly data from ferry crossings in 2003 and 2004 (Qurban, 2009) suggests that the pattern of diatom biomass observed is not unique (see Fig. 6). A similar pattern is seen in Qurban's data in 2004 (redrawn in Fig. 6b), which clearly shows diatoms between $46^{\circ} \mathrm{N}$ and $47^{\circ} \mathrm{N}$ around Day 105 and then off Brittany in the western English Channel around Day 196, 
(a)

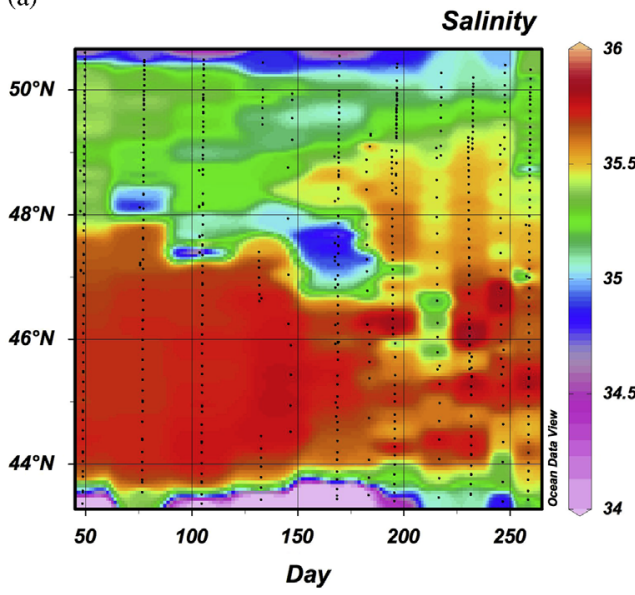

(c)

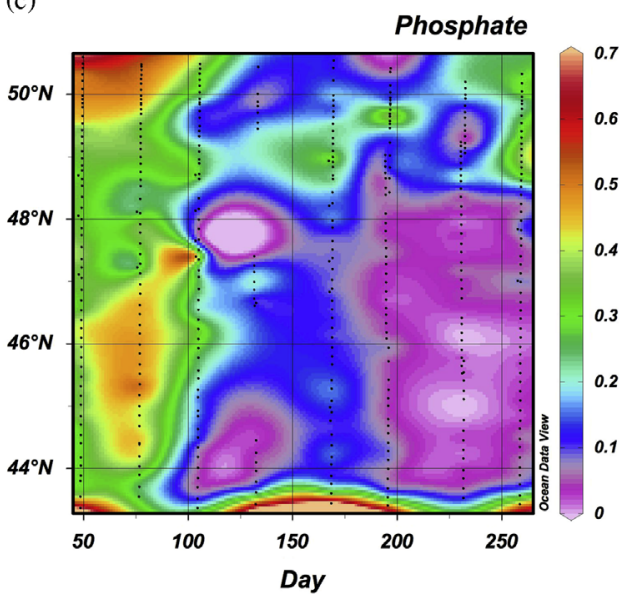

(b)

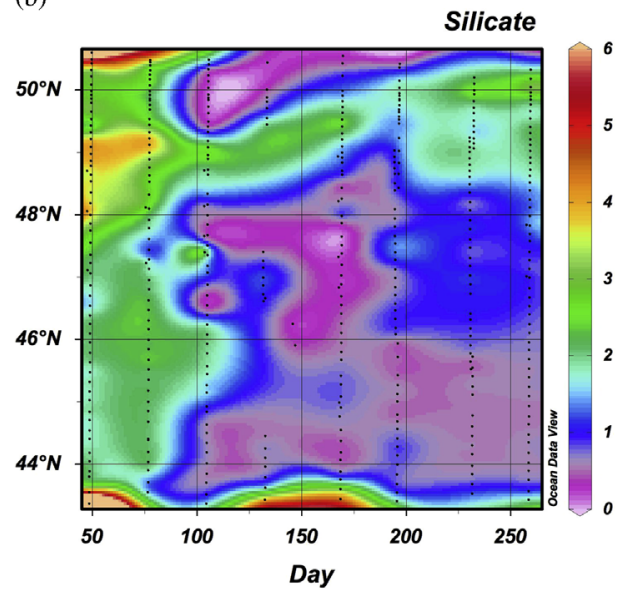

(d)

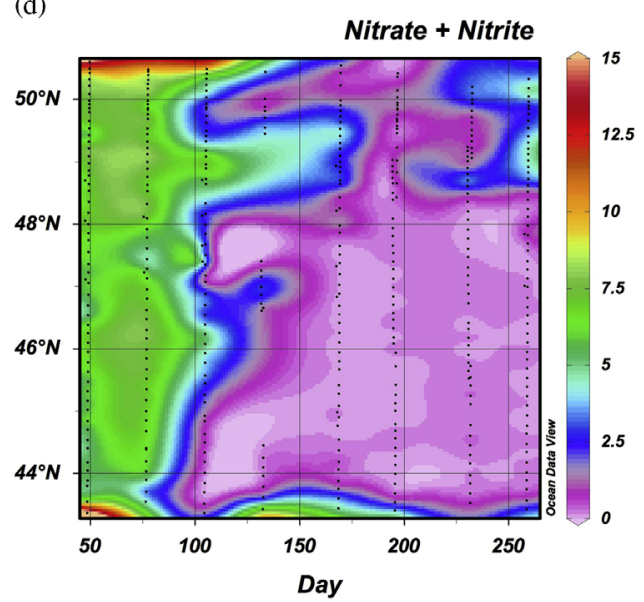

Fig. 4. The distribution of (a) salinity (PSU), (b) silicate $\left(\mu \mathrm{mol} \mathrm{kg}{ }^{-1}\right),(\mathrm{c})$ phosphate $\left(\mu \mathrm{mol} \mathrm{kg}{ }^{-1}\right)$ and $(\mathrm{d})$ nitrate $\left(\mu \mathrm{mol} \mathrm{kg}{ }^{-1}\right)$ in 2010 .

slightly later than our observations. Here Guinardia sp. are reported to be the most dominant species. It could be argued that the pattern in 2003 is vaguely similar but the concentration of diatoms is much lower and Qurban (2009) reports mainly comprise pseudo-Nitzschia.

\subsection{Coccolithophores}

Following almost directly on from the diatom bloom, the coccolithophore bloom stretches the entire length of the Bay of Biscay with high spots around $46^{\circ} \mathrm{N}$, off the Brittany coast at $48^{\circ} \mathrm{N}$ and in the western English Channel (Day 147, Fig. 5g). Coccolithophores in these regions at this time of year are well documented (Holligan et al., 1983; Garcia-Soto and Pingree, 1998, 2009; GarciaSoto et al., 1995; Harlay et al., 2010; Daniels et al., 2012) and are clearly visible from the milky colour on satellite images and airborne studies (Garcia-Soto et al., 1996). It has been suggested that their occurrence takes advantage of the higher calcite saturation left after the diatom bloom (Harlay et al., 2010). Comparison with the 2003 and 2004 data from Qurban (2009) shows that bloom conditions in 2010 are again more similar to 2004, than 2003 (see Fig. 6c) with low concentrations and a narrow band within the Bay of Biscay and English Channel around Day 150. What is interesting is that the bloom appears to be shorter lived in 2010 than in previous years. Coccolithophores data available for 2006, 2008 and 2009 along the ferry route (Tyrell, 2011) show similar patterns but with higher cell concentration $\left(\times 10^{2}\right)$.

\subsection{Dinoflagellates}

It would appear that dinoflagellates are present off the coast of Brittany and in the English Channel for much of the year and in general the 2010 distribution throughout the entire route is more similar to 2003 rather than 2004 (see Fig. 6d). The distribution in the Channel is particularly interesting. Fig. 7a-d shows more clearly, in a west to east orientation, the very high patches of chlorophyll-a $\left(13.6 \mu \mathrm{g} \mathrm{L}^{-1}\right)$, fucoxanthin $\left(2.6 \mu \mathrm{g} \mathrm{L}^{-1}\right)$, and dinoflagellate counts $\left(0.8 \times 10^{6}\right.$ cells $\left.\mathrm{L}^{-1}\right)$ between $3^{\circ} \mathrm{W}$ and $4^{\circ} \mathrm{W}$ on Day 196 in 2010. In contrast, peridinin is highest at this location on Day 169 and Day 217, and further west around $5^{\circ} \mathrm{W}$ on Day 196. The closer association of the dinoflagellates with the pigment fucoxanthin, normally the marker for diatoms, rather than peridinin, suggests the presence of toxic dinoflagellates (Hackett et al., 2004) between $3^{\circ} \mathrm{W}$ and $4^{\circ} \mathrm{W}$. This is corroborated by the presence of unquantified amounts of the pigment gyroxanthin-diester, a known marker pigment for Karenia sp. (Stæhr and Cullen, 2003; Örnólfscóttir and Pinckney, 2003). The microscope counts reveal that this is a bloom of Karenia Mikimotoi, (Fig. 7e), which is a species that has raised environmental concerns associated with the mortality of fish and other marine fauna and anoxia in many regions of the world, mainly in coastal waters (Brand et al., 2012; Raine et al., 2001; Silke et al., 2005; Tangen, 1977). However, there are no published results suggesting toxicity to humans or marine organisms in the open ocean regions of the Bay of Biscay and English Channel and the evidence from the 2010 study is unable to confirm or refute a toxic effect. 

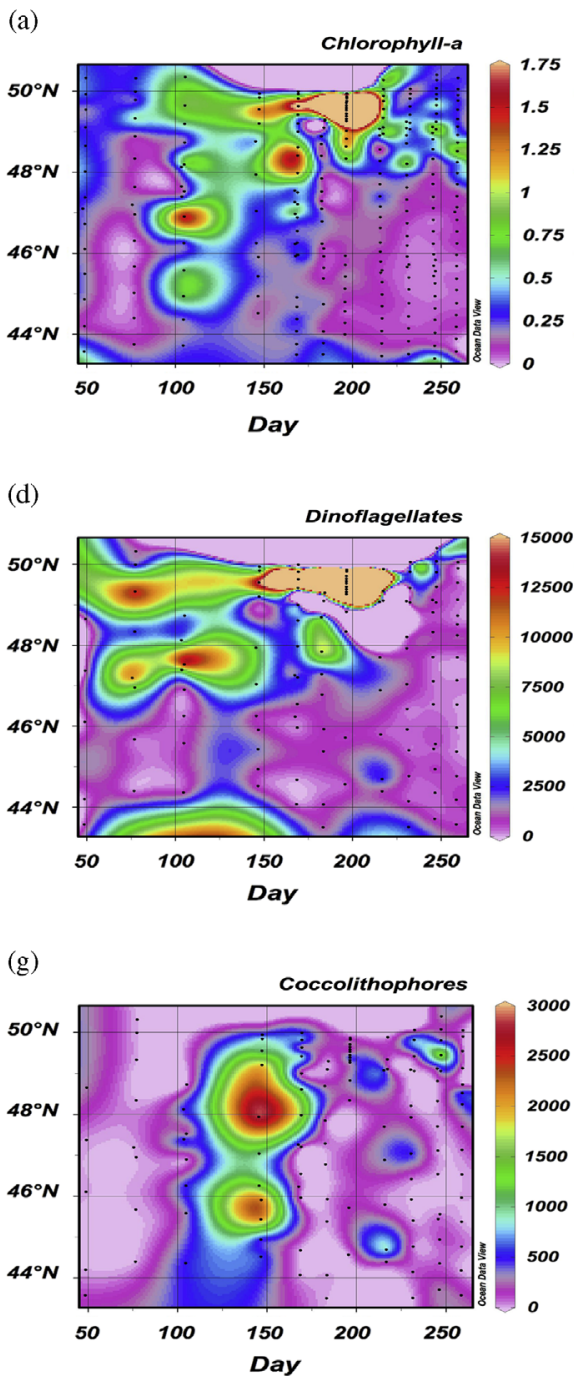
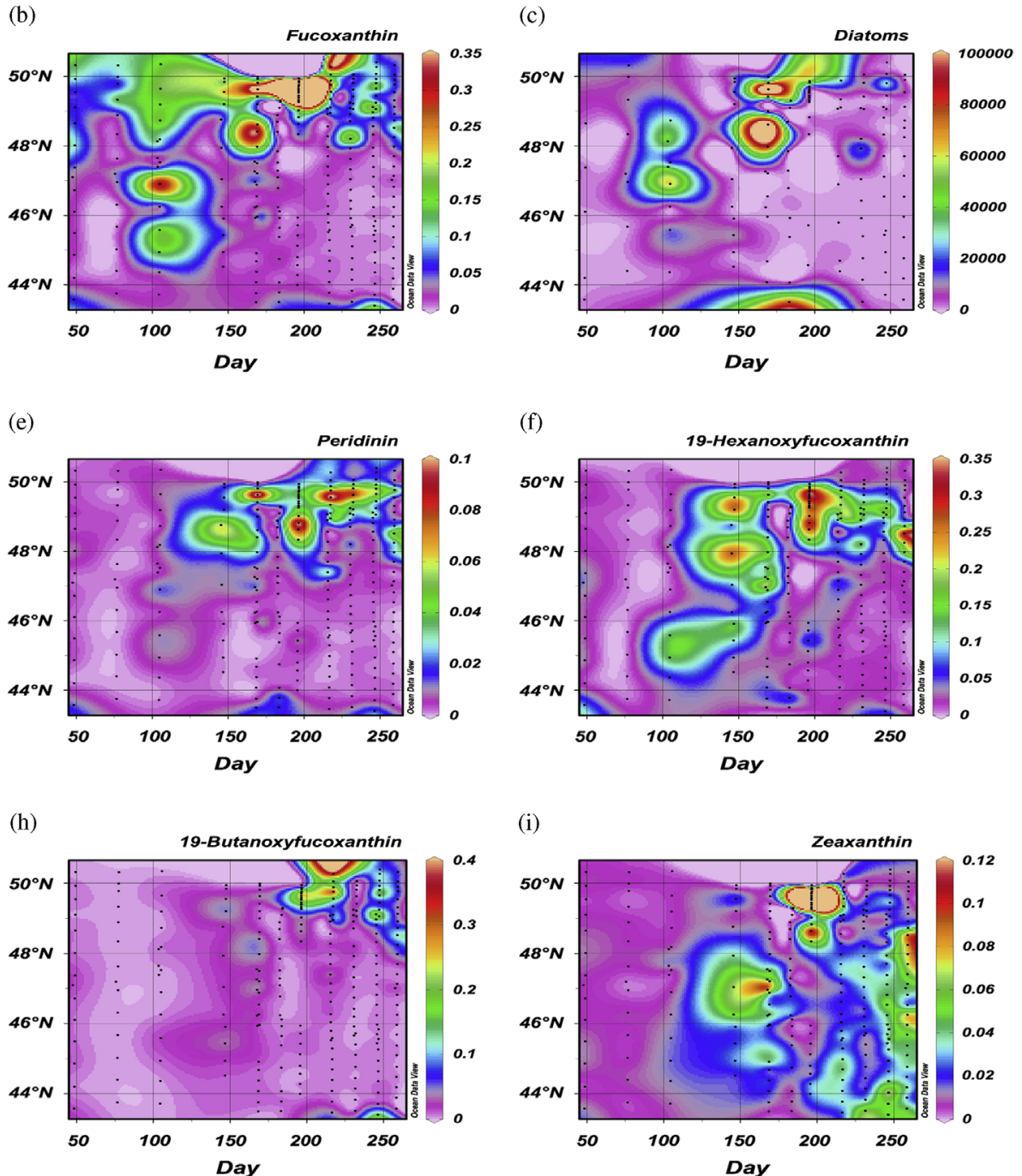

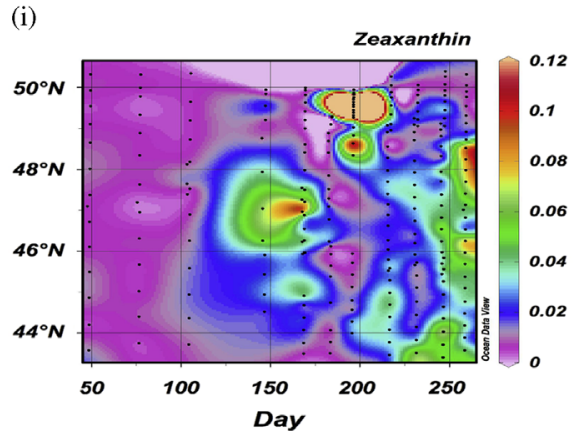

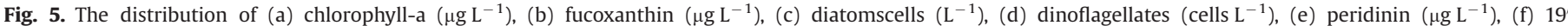
hexanoxyfucoxanthin $\left(\mu \mathrm{g} \mathrm{L}^{-1}\right),(\mathrm{g})$ coccolithophores (cells $\left.\mathrm{L}^{-1}\right),(\mathrm{h}) 19^{\prime}$ butanoxyfucoxanthin $\left(\mu \mathrm{L} \mathrm{L}^{-1}\right)$ and (i) zeaxanthin $\left(\mu \mathrm{g} \mathrm{L}^{-1}\right)$ in 2010 .

Karenia sp. ( $>100$ cells $\mathrm{L}^{-1}$ ) occurs along the southern coast of Cornwall and western Devon (UK) during most summers (Widdicombe et al., 2010; Coates et al., 2010). However, large blooms in the central western Channel are infrequent, but were seen by Qurban in 2003 (but not in 2004) and subsequently modelled by Vanhoutte-Brunier et al. (2008), and also seen at the same time and location in earlier years by Pingree et al. (1975, 1977). Garcia-Soto and Pingree (2009) provides an analysis of the summer blooms of phytoplankton in the central western English Channel for the years 1997-2007, with direct observations of large-scale red colour blooms from satellite for the years 2000, 2002, 2003, 2004 and 2006. Such blooms have been associated with an influx of nitrate and phosphate following mixing (Pingree et al., 1977) and with fresh water that has been transported from the Loire and Gironde estuaries (KellyGerreyn et al., 2006). The salinity distribution in Fig. 4 shows the presence of lowish salinity water in the English Channel in 2010 $(<35.25)$ and its association with higher nutrients. This and the previous studies suggest that the Karenia Mikimotoi bloom in the English Channel sits within very specific geographical space; it is likely related to prevailing hydrological and wind conditions, nutrient availability and sunlight as indicated by other authors. The factors that influence Karenia sp. occurrence are reviewed by Gentien (1998) and further discussed in Davidson et al. (2009), Garcia-Soto and Pingree (2009), Pybus (1980) and Hartman et al. (in revision).
While Karenia Mikimotoi is the most dominate species on Day 196 the bloom also contains other dinoflagellates (e.g. Gymnodinium sp. $\sim 131,000$ cells $\mathrm{L}^{-1}$ ) and some diatoms (Nitzschia sp. and Navicula sp. $\sim 8000$ cells $\mathrm{L}^{-1}$ ) and together the large bloom totally depletes the water of nitrate. The spread of the peridinin data suggests that dinoflagellates are also present from June to August. Fig. 7(f) shows the concentration of dinoflagellates other than Karenia Mikimotoi to be $\sim 80,000$ cells $\mathrm{L}^{-1}$ (primarily Prorocentrum sp. and Alexandrium sp.) on Day 169 (June 18th); unfortunately there is no confirmatory taxonomy for Day 217 (5th August). This compares well with Qurban's data for 2004 (see Fig. 6d), which shows dinoflagellates concentrations of $\sim 52,000$ cells $\mathrm{L}^{-1}$ in a year when Karenia Mikimotoi was virtually absent. This suggests that Karenia Mikimotoi augment a regularly occurring dinoflagellate bloom rather than replacing it and would support the idea that they flourish only when specific environmental conditions occur (Gentien, 1998).

\section{Conclusion}

There are very distinctive patterns in phytoplankton distributions and successions along the MV Pride of Bilbao route in the Bay of Biscay and English Channel that have been seen in 2003, 2004 and 2010. In the Bay, the spring bloom of diatoms coincides with 
(a)

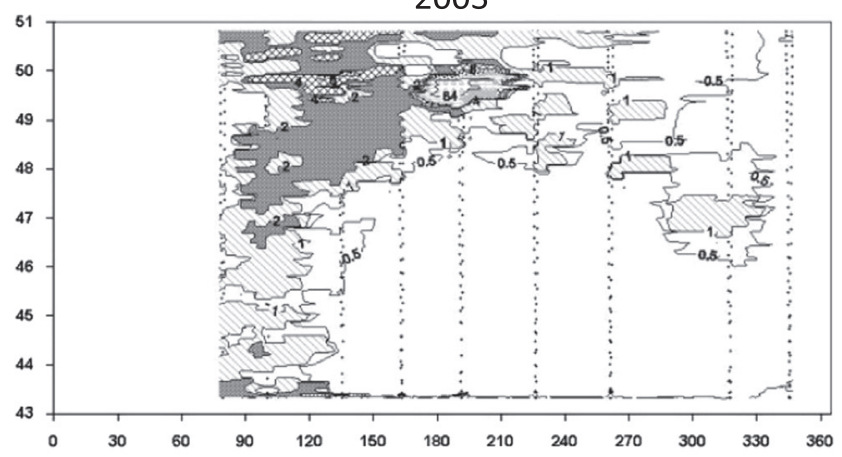

(b)

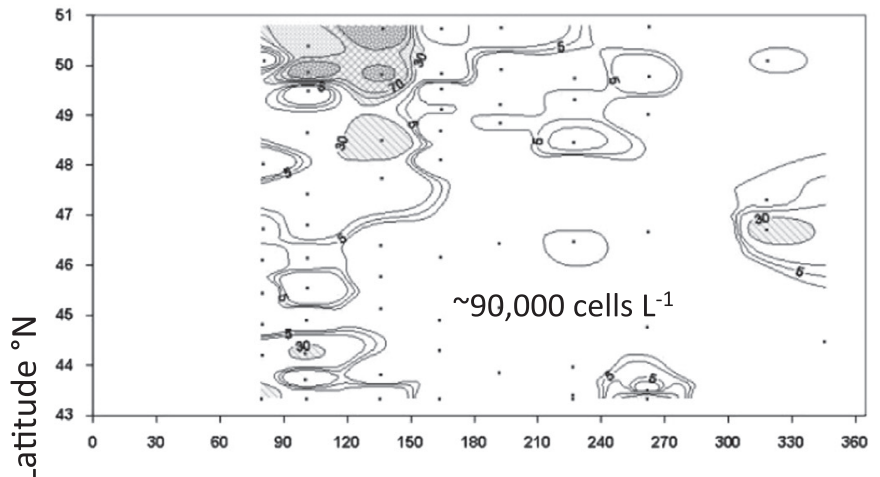

(c)

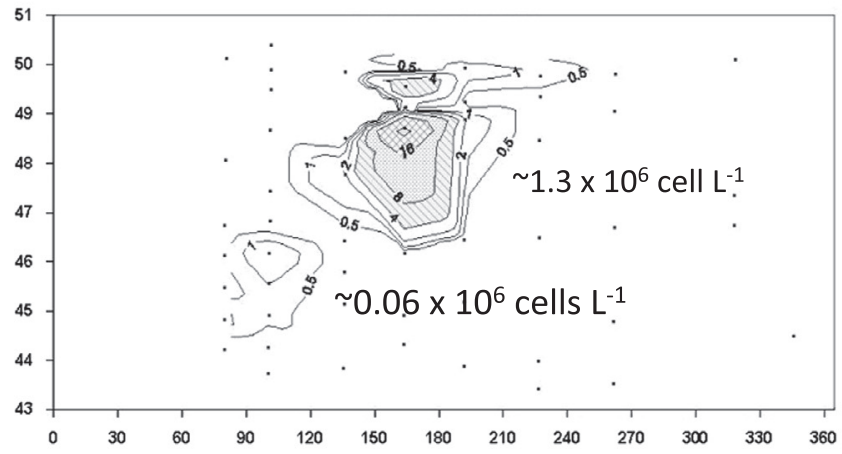

(d)

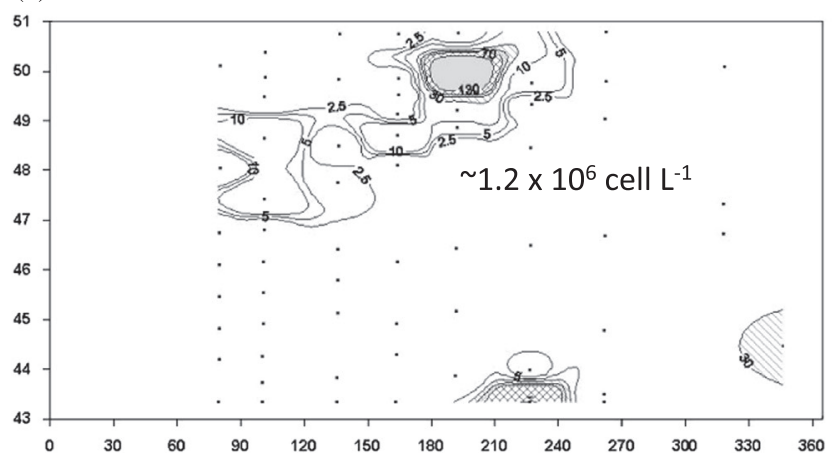

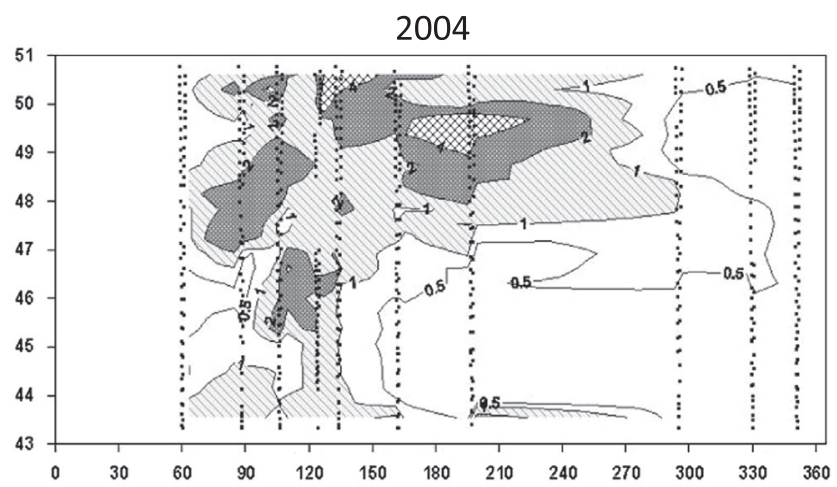

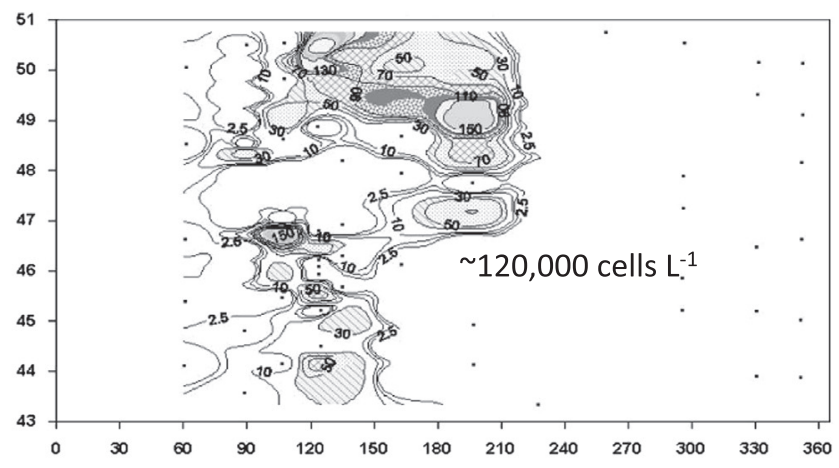

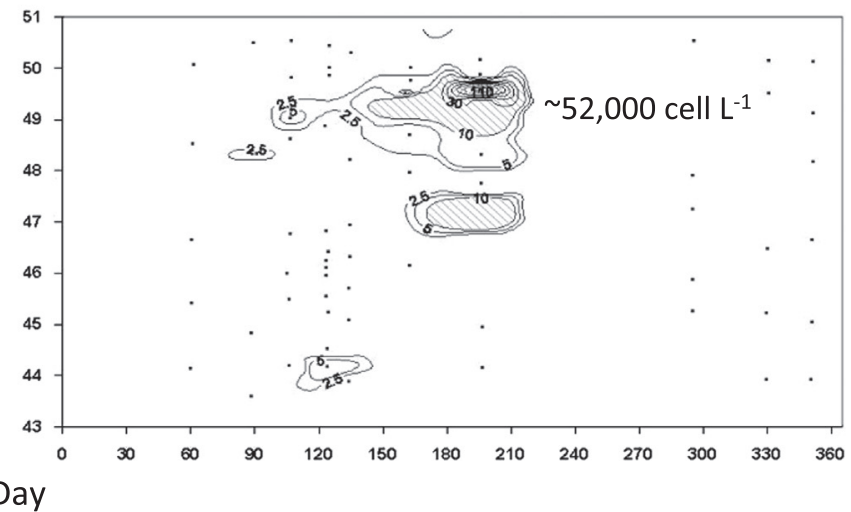

Fig. 6. The distribution of (a) chlorophyll-a $\left(\mathrm{mg} \mathrm{m}^{-3}\right.$ ) and (b) diatoms (c) coccolithophores and (d) dinoflagellates shown in terms of biomass ( $\mathrm{mg} \mathrm{m}^{-3}$ ) in 2003 and 2004 ; reproduced from Qurban (2009). Cell counts are those reported by Qurban (2009).

surface stabilisation and temperatures reaching $12{ }^{\circ} \mathrm{C}$ and the timing varies little from year to year, the bloom occurring in mid-April. This timing is consistent with the conclusions of GarciaSoto and Pingree (1998). After this, silicate concentrations fall to
$<0.1 \mu \mathrm{mol} \mathrm{kg}{ }^{-1}$ suggesting that silicate may be limiting. Coccolithophores immediately follow the diatom bloom and again their year on year occurrence shows the same general pattern with some variation in abundance. Following the coccolithophore bloom 
(a)

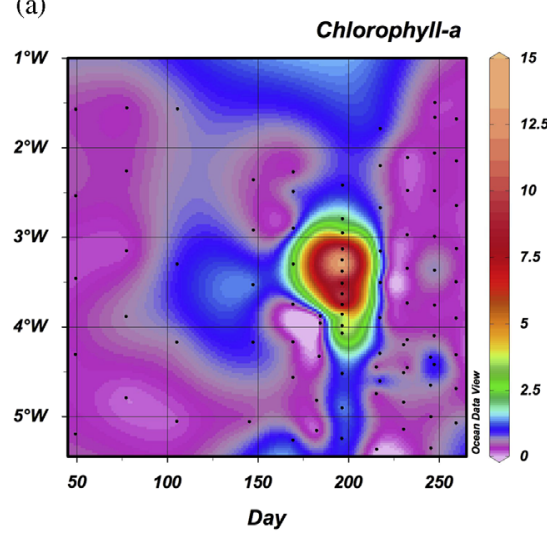

(d)

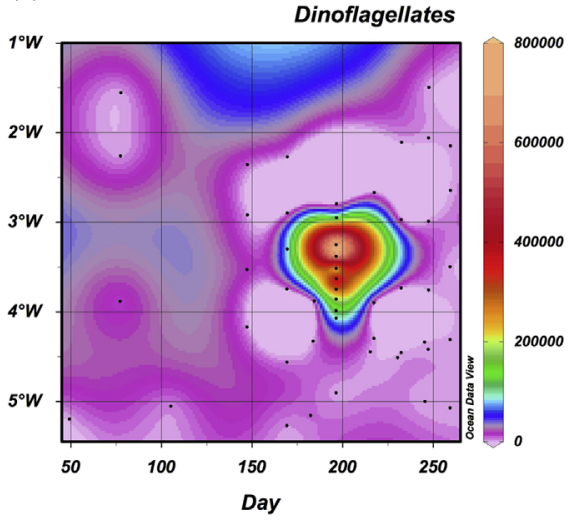

(b)

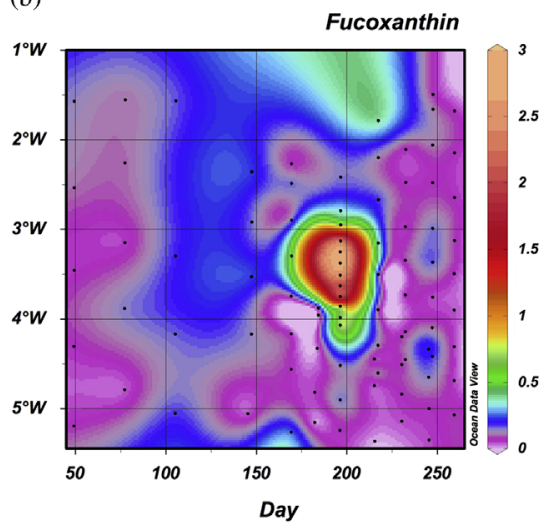

(e)

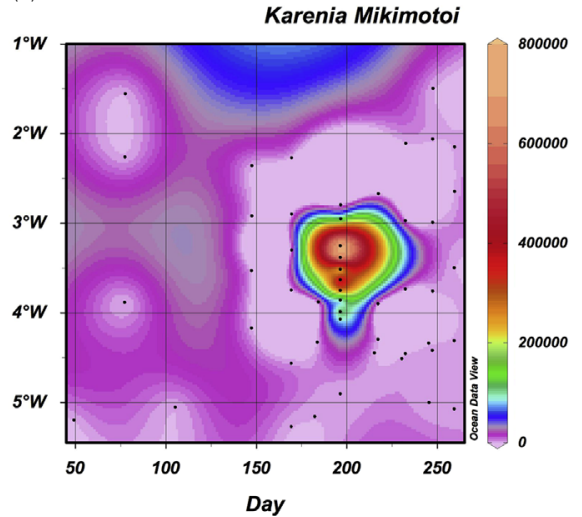

(c)

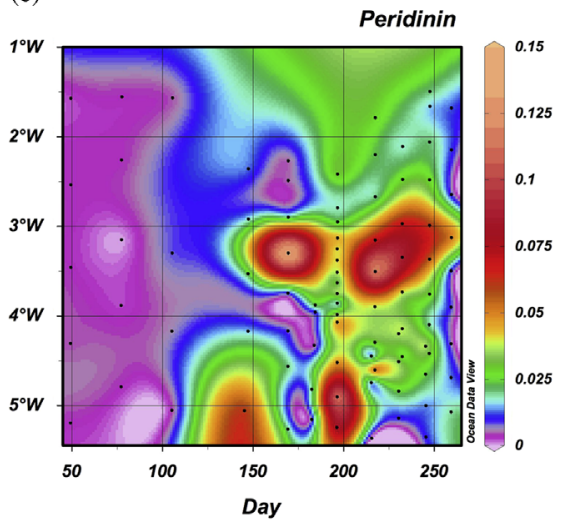

(f)

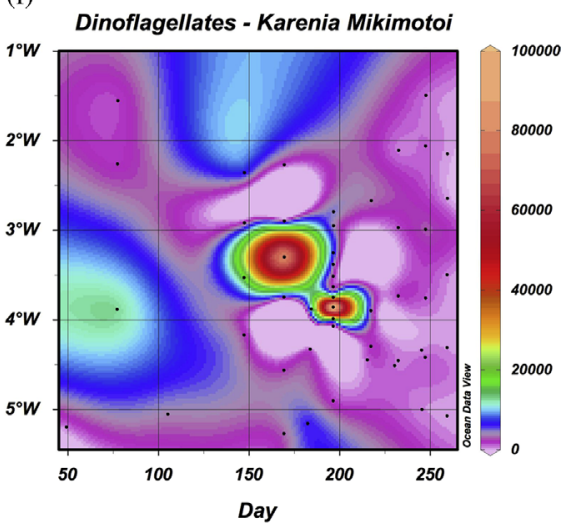

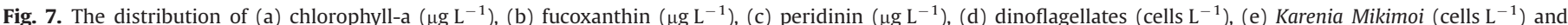
(f) dinoflagellates excluding Karenia Mikimoi (cells L ${ }^{-1}$ ), in the English Channel in 2010.

in May, phosphate and nitrate fall to $<0.1$ and $<0.2 \mu \mathrm{mol} \mathrm{kg} \mathrm{kg}^{-1}$ respectively and phytoplankton growth during the summer is nutrient limited. From the spread of the pigment zeaxanthin it would appear that prochlorophytes, that thrive in low nutrient environments, dominate during the summer and autumn. Year to year comparisons would suggest that the populations in 2010 more closely follow those in 2004 rather than 2003 and this may be due to wind conditions causing intermittent turbulence in the upper waters resulting in higher nitrate concentrations. Both Qurban (2009) and Hartman et al. (2013) show nitrate to be higher in the Bay of Biscay in 2004 than in 2003, and Hartman et al. (2013) report it even higher in 2010. In addition, Jan-March winds in the Bay of Biscay in 2010 (UK Met Office, 2010a) and in 2004 (Qurban, 2009) were strong south-westerlies, whereas in 2003 they were predominately weaker easterlies, (Qurban, 2009).

Moving northward off Ushant, the coastal phytoplankton populations are mixed and more variable due to the energetic tidal mixing. Here, diatoms and coccolithophores bloom in normal succession and dinoflagellates are seen in most seasons, agreeing with other studies. Along the MV Pride of Bilbao route, nutrients do not seem to be limiting as here sporadic populations occur throughout the summer. However in 2010, nitrate was depleted by the unusual occurrence of a bloom of the toxic dinoflagellate Karenia mikimotoi in the centre of the western English Channel. Such a bloom was also evident in 2003, but not in 2004, and again its occurrence may be wind related. In 2003 (Qurban, 2009) and in late 2009 and throughout much of the spring and early summer (Jan-June) 2010 the winds in the Channel where southwesterly (UK Met Office, 2010b) whereas in 2004 they were northwesterly (Qurban, 2009). While various suggestions have been put forward as to the reasons for the infrequent occurrence of intense summer blooms of Karenia Mikimotoi in the shallow thermocline regions of the western English Channel they are not conclusive (KellyGerreyn et al., 2006; Vanhoutte-Brunier, 2008). A basic understanding of phytoplankton bloom development in the region is discussed in previous papers (Pingree et al., 1976, 1977, 1978, 1982; Garcia-Soto and Pingree, 1998, 2009). Most recently, some factors affecting the Karenia Mikimotoi bloom in 2010 compared to previous years are discussed in Hartman et al. (in revision).

Finally, since the year-to-year variations we examined seem to be relatively minor in the central Bay of Biscay, we suggest that this region is not influenced too much by changes in the NAO index, which is consistent with the findings of others (Garcia-Soto and Pingree, 2009; Fernandez et al., 1993; Varela, 1996). Hartman et al. (2013) suggests that winter NAO influences winter nitrate levels and minimum sea surface temperatures which is consistent with different wind conditions with positive and negative winter NAO. These responses are discussed in detail for the North Atlantic in Garcia-Soto and Pingree (2012). Further north to the stratified side of the Ushant front and in the English Channel a limited NAO influence is not necessarily true. Here stronger variable winds (UK Met Office) give rise to more energetic mixing that influences the occurrence and duration of the blooms.

\section{Acknowledgments}

We would like to express our thanks to the officers and crew of the P\&O vessel MV Pride of Bilbao and to Jon Campbell, Kevin Saw and other members of the engineering staff at the National Oceanography Centre for their unfailing help in setting up and commissioning equipment. We are also grateful to a number of students who assisted with the twice monthly sampling and to a reviewer who added to the manuscript by providing detailed 
knowledge of previous work in the region. The work was funded by the European Union FP7-ENV-2008-1, Grant Agreement no. 226880 (http://www.protool-project.eu).

\section{References}

Ayres, P.A., Cullum, M., 1978. Paralytic shellfish poisoning: an account of the investigations into mussel toxicity in England, 1968-1982. Fisheries Research Technical Report. vol. 40, pp. 1-23.

Ayres, P.A., Seaton, D.D., Tett, P.B., 1982. Plankton blooms of economic importance to fisheries in U.K. waters 1968-1982. ICES CM 1982/L 38, 21.

Bates, N.R., Best, M.H.P., Neely, K., Garley, R., Dickson, A.G., Johnson, R.J., 2012. Detecting anthropogenic carbon dioxide uptake and ocean acidification in the North Atlantic Ocean. Biogeosci. Discuss. 9 (-), 989-1019.

Barlow, R.G., Mantoura, R.F.C., Gough, M.A., Fileman, T.W., 1993. Pigment signatures of phytoplankton composition in the north-eastern Atlantic during the 1990 spring bloom. Deep-Sea Res. 40, 459-477.

Beaugrand, G., Reid, P.C., 2003. Long-term changes in phytoplankton, zooplankton and salmon related to climate. Glob. Change Biol. 9, 801-817.

Beaugrand, G., Edwards, M., Brander, K., Luczak, C., Ibanez, F., 2008. Causes and projections of abrupt climate driven ecosystem shifts in the North Atlantic. Ecol. Lett. 11, 1157-1168.

Beaugrand, G., Ibanez, F., Reid, P.C., 2000. Spatial, seasonal and long-term fluctuations of plankton in relation to hydroclimatic features in the English Channel, Celtic Sea and Bay of Biscay. Mar. Ecol. Prog. Ser. 200, 93-102.

Behrenfeld, M.J., Halsey, K.H., Milligan, A.J., 2008. Evolved physiological responses of phytoplankton to their integrated growth environment. Philos. Trans. R. Soc. B: Biol. Sci. 363, 2687-2703.

Bjørnland, T., Liaaen-Jensen, S., 1989. Distribution patterns of carotenoids in relation to chromophyte phylogeny and systematics, The Chromophyte Algae: Problems and Perspectives. Clarendon Press, Oxford p. 1989

Boyce, D.G., Lewis, M.R., Worm, B., 2010. Global phytoplankton decline over the past century. Nature 466, 591-596, http://dx.doi.org/10.1038/nature09268.

Brand, L.E., Campbell, L., Bresnan, E., 2012. Karenia: the biology and ecology of a toxic genus. Harmful Algae 14, 156-178.

Coates, L., Morris, S., Myriam Algoet, M., Higman, W., Forster, R., Stubbs, B. 2010 A Karenia mikimotoi bloom off the southern coast of Cornwall in August 2009: The results from the biotoxin monitoring programme for England and Wales. 〈www.cefas.defra.gov.uk/media/445880/karenia.pdf〉.

Daniels, C.J., Tyrell, T., Poulton, A.J., Pettit, L., 2012. The influence of lithogenic material on particulate inorganic carbon measurements of coccolithophores in the Bay of Biscay. Limnol. Oceanogr. 57, 145-153.

Davidson, K., Gillibrand, P., Wilding, T., Miller, P. and Shutter, J.., 2009. Predicting the progression of the harmful dinoflagellate Karenia mikimotoi along the Scottish coast and potential impact for fish farming. The Crown Estate, 101pp. ISBN 978 $1-906410-06-3$.

Elderfield, H., 2002. Carbonate mysteries. Science 296, 1618-1621, http://dx.doi. org/10.1126/science.1072079.

Fenchel, T., 1988. Marine plankton food chains. Ann. Rev. Ecol. Syst. 19, 19-38.

Fernandez, E., Cabal, J., Acuna, J.L., Bode, A., Botas, A., Garca-Soto, C., 1993. Plankton distribution across a slope current-induced front in the southern Bay of Biscay. J. Plankton Res. 15, 619-641.

Garcia-Soto, C., Fernandez, E., Pingree, R.D., Harbour, D.S., 1995. Evolution and structure of a shelf coccolithophores bloom in the Western English Channel J. Plankton Res. 17, 2011-2036.

Garcia-Soto, C., Pingree, R.D., 1998. Late autumn distribution and seasonality of chlorophyll-a at the shelf-break/slope region of the Armorican and Celtic shelf J. Mar. Biol. Assoc., UK 78, 17-33.

Garcia-Soto, C., Pingree, R.D., 2009. Spring and summer blooms of phytoplankton (SeaWifs/MODIS) along a ferry line in the Bay of Biscay and western English Channel. Cont. Shelf Res. 29, 1111-1122.

Garcia-Soto, C., Pingree, R.D., 2012. Atlantic Multidecadal Oscillation (AMO) and sea surface temperature in the Bay of Biscay and adjacent regions. J. Mar. Biol. Assoc., UK 92, 213-234.

Garcia-Soto, C., Sinha, B., Pingree, R.D., 1996. Mapping a bloom of the coccolithophore Emiliania huxleyi from Airborne Thematic Mapper data. J. Mar. Biol. Assoc., UK 76, 839-849.

Gentien, P., 1998. Bloom dynamics and ecophysiology of the Gymnodinimum mikimotoi species complex. In: Anderson, D.M., et al. (Eds.), Physiological Ecology of Harmful Algal Blooms, NATO ASI series, vol. G41. Springer-Verlag, Berlin, pp. 155-173.

Gibb, S.W., Cummings, D.G., Irigoien, X., Barlow, R.G., Mantoura, R.F.C., 2001 Phytoplankton pigment chemotaxonomy of the northeastern Atlantic. DeepSea Res. 48, 795-823.

González, N., Anadón, R., Viesca, L., 2003. Carbon flux through the microbial community in a temperate sea during summer: role of bacterial metabolism. Aquat. Microb. Ecol. 33, 117-126.

Grasshoff, K., 1983. Determination of nutrients. In: Grassoff, K., M. Ehrhardt, M. Kremling, K. (Eds.), Methods of Seawater Analysis, 2nd ed. Verlag Chemie GmbH, Basel, pp. 125-188 (pp. 419)

Hackett, J.D., Anderson, D.M., Erdner, D.L., Hattacharya, D., 2004. Dinoflagellates: a remarkable evolutionary experiment. Am. J. Bot. 91, 1523-1534.

Harlay, J., Borges, A.V., Van Der Zee, C., Delille, B., Godoi, R.H.M., Schiettecatte, L.-S., Roevros, N., Aerts, K., Lapernat, P.-E., Rebreanu, L., Groom, S., Daro, M.-H., Van
Grieken, L., Chou, L., 2010. Biogeochemical study of a cocolithophore bloom in the northern Bay of Biscay (NE Atlantic Ocean) in June 2004. Prog. Oceanogr. 86, 317-336.

Hartman, S.E., Hartman, M.C., Hydes, D.J., Jiang, Z.-P. and Smythe-Wright, D., 2013. Seasonal and inter-annual variability in nutrient supply in relation to mixing in the Bay of Biscay. Deep-Sea Res. II http://dx.doi.org/10.1016/j.dsr2.2013.09.032.

Hartman, S., Hartman, M., Hydes, D.J., Lazure, P., Smythe-Wright, D., and Gohin, F., Karenia Mikimotoi observations from a ship of opportunity in the English Channel in relation to hydrographical and meteorological features. J. Mar. Syst. in revision.

Hasle, G., 1978. The inverted microscope method. In: Sournia, A. (Ed.), In Phytoplankton Manual. UNESCO, Paris

Holligan, P.M., Viollier, M., Harbour, D., Camus, P., Champagne-Philippe, M., 1983. Satellite and ship studies of coccolithophore production along a continental shelf edge. Nature 304, 339-342.

Hydes, D.J., Yool, A.,Campbell, J.M., Crisp, N.A., Dodgson, J., Dupee, B., Edwards, M., Hartman, S.E., Kelly-Gerreyn, B.A., Lavin, A.M., Gonzalez-Pola, C.M., Miller, P., 2003. Use of a Ferry-Box system to look at shelf sea and ocean margin processes. In: Dahlin, H., et al. (Eds.), Building the European capacity in operational oceanography. Proceedings of the 3rd International Conference on EuroGOOS. 3-6 December, 2002, Athens, Greece. Elsevier Oceanography Series, vol. 69, pp. 297-303.

Jeffrey, S.W., Mantoura, R.F.C., 1997. Development of pigment methods for oceanography. In: Jeffrey, S.W., Mantoura, R.F.C., Wright, S.W. (Eds.), Phytoplankton Pigments in Oceanography: Guidelines to Modern Methods. UNESCO Monographs in Oceanographic Methods. SCOR WH 78, Paris.

Karl, D.M., Church, M.J., Dore, J.E., Letelier, R.M., Mahaffey, C., 2012. Predictable and efficient carbon sequestration in the North Pacific Ocean supported by symbiotic nitrogen fixation. Proc. Natl. Acad. Sci. 109, 1842-1849.

Kelly-Gerreyn, B.A., Hydes, D.J., Jegou, A.M., Lazure, P., Fernand, L.J., Puillat, I., Garcia-Soto, C., 2006. Low salinity intrusions in the western English Channel. Cont. Shelf Res. 26, 1241-1257, http://dx.doi.org/10.1016/j.csr.2006.03.007.

Laiz, I., Ferrer, L., Plomaritis, T., Charria, G., 2014. Effect of river runoff on sea level from in-situ measurements and numerical models in the Bay of Biscay. DeepSea Res. II 106, 49-67, http://dx.doi.org/10.1016/j.dsr2.2013.12.013.

MCCIP, 2010. Marine Climate Change Impacts Annual Report Card 2010-2011. Baxter, J.M, Buckley, P.J., Wallace, C.J., (Eds.), Summary Report, MCCIP, Lowestoft, 12 pp.

Mc Quatters-Gollop, A., Reid, P.C., Edwards, M., Burkill, P.H., Castellani, C., Batten, S., Gieskes, W., Beare, D., Bidigare, R.R., Head, E., Johnson, R., Kahru, M., Koslow, J. A., Pena, A., 2011. Is there a decline in marine phytoplankton? Nature 472, E6-E7, http://dx.doi.org/10.1038/nature09950.

Moestrup, O., Akselman, R., Cronberg, G., Elbraechter, M., Fraga, S., Halim, Y., Hansen, G., Hoppenrath, M., Larsen, J., Lundholm, N., Nguyen, L.N., Zingone, A. (Eds.), 2009 onwards. IOC-UNESCO Taxonomic Reference List of Harmful Micro Algae. Available online at $\langle$ http://www.marinespecies.org/HAB $\rangle$. (accessed 07.06.12).

Örnólfsdóttir, E.B., Pinckney, J.L., 2003. Quantification of the relative abundance of the toxic dinoflagellate, Karenia Brevis (Dinophyta), using unique phytopigments. J. Phycol. 39, 449-457.

Pingree, R.D., 1975. The advance and retreat of the thermocline on the continental shelf. J. Mar. Biol. Assoc., UK 55, 965-974.

Pingree, R.D., 1977. Mixing and stabilisation of phytoplankton distribution in the northwest European continental shelf. In: Steele., J.H. (Ed.), Spatial Pattern in Plankton Communities. Plenum Press, New York, pp. 181-220

Pingree, R.D., 1980. Physical oceanography of the Celtic sea and English Channel. In: Banner, F.M., Collins, K.M. (Eds.), The North-West European Shelf Seas: The Sea Bed and Sea in Motion. II. Physical and Chemical Oceanography, and Physical Resources. Elsevier Scientific Publishing Company, Amsterdam, pp. 415-465

Pingree, R.D., Griffiths, D.K., 1978. Tidal fronts on the shelf seas around the British Isles. J. Geophys. Res. 83, 4615-4622.

Pingree, R.D., Holligan, P.M., Head, R.N., 1977. Survival of dinoflagellate blooms in the western English Channel. Nature 265, 266-269.

Pingree, R.D., Holligan, P.M., Mardell, G.T., 1978. The effects of vertical stability on phytoplankton distributions in the summer on the north west European Shelf. Deep-Sea Res. 25, 1011-1028.

Pingree, R.D., Holligan, P.M., Mardell, G.T., Head, R.N., 1976. The influence of physical stability on spring, summer and autumn phytoplankton blooms in the Celtic Sea. J. Mar. Biol. Assoc., UK 576, 845-873.

Pingree, R.D., Maddock, L., Butler, E.I., 1977. The influence of biological activity and physical stability in determining the chemical distribution of inorganic phosphate, silicate and nitrate. J. Mar. Biol. Assoc., UK 57, 1065-1073.

Pingree, R.D., Mardell, G.T., Holligan, P.M., Griffiths, D.K., Smithers, J., 1982. Celtic Sea and Armorican current structure and the vertical distributions of temperature and chlorophyll. Cont. Shelf Res. 1, 99-116.

Pingree, R.D., Pennycuick, L., 1975. Transfer of heat, fresh water and nutrients through the seasonal thermocline. J. Mar. Biol. Assoc., UK 55, 261-274.

Pingree, R.D., Pugh, P.R., Holligan, P.M., Forster, G.R., 1975. Summer phytoplankton blooms and red tides along tidal fronts in approaches to English channel. Nature 258, 672-677.

Puillat, I., Lazure, P., Jégou, A.M., Lampert, L., Miller, P.I., 2004. Hydrographical variability on the French continental shelf in the Bay of Biscay, during the 1990s. Cont. Shelf Res. 24, 1143-1163.

Pybus, C., 1980. Observations on a Gyrodinium aureolum (Dinophyta) bloom off the south coast of Ireland. J. Mar. Biol. Assoc., UK 60, 661-674. 
Qurban, M.A.B., 2009. An Investigation of the Factors Influencing the Spatial and Temporal Distribution of Surface Phytoplankton in the English Channel and Bay of Biscay in 2003 and 2004 (PhD thesis). University of Southampton, UK.

Raine, R., O'Boyle, S., O'Higgins, T., White, M., Patching, J., Cahill, B., McMahon, T., 2001. A satellite and field portrait of a Karenia mikimotoi bloom off the south coast of Ireland, August 1998. Hydrobiologia 465, 187-193.

Reid, P., Johns, D., Edwards, M., Starr, M., Poulin, M., Snoejis, P., 2007. A biological consequence of reducing Arctic ice cover: arrival of the Pacific diatom Neodenticula seminae in the North Atlantic for the first time in 800,000 years. Global Change Biol. 13, 1910-1921.

Roach, J., 2004. Source of Half Earth's Oxygen Gets Little Credit. National Geographic News June 7. 〈http://news.nationalgeographic.com/news/2004/06/ 0607_040607_phytoplankton.html>.

Sarmiento, J.L., Slater, R., Barber, R., Bopp, L., Doney, S.C., Hirst, A.C., Kleypas, J., Matear, R., Mikolajewicz, U., Monfray, P., Soldatov, V., Spall, S.A., Stouffer, R., 2004. Response of ocean ecosystems to climate warming. Global Biogeochem. Cycles 18, GB3003, http://dx.doi.org/10.1029/2003GB002134.

Schlitzer, R., 2008. Ocean Data View, 〈http://odv.awi.deS〉.

Silke, J., O’Beirn, F., Cronin, M., 2005. Karenia Mikimotoi : An exceptional dinoflagellate bloom in western Irish waters, summer 2005. Marine Institute Marine Environment and Food Safety Services Galway. issn:1649-0053.

Stæhr, P.A., Cullen, J.J., 2003. Detection of Karenia mikimotoi by spectral absorption signatures. J. Plankton Res. 25, 1237-1249.

Tangen, K., 1977. Blooms of Gyrodinium aureolum (Dinophyceae) in north European waters, accompanied by mortality in marine organisms. Sarsia 63, 123-133.
Tomas, C.R., 1997. Identifying Marine Phytoplankton. Academic Press, New York p. 858 Turner, M.F., Bullock, A.M., Tett, P., Roberts, R.J., 1987. Toxicity of Gyrodinium aureolum; some initial findings. Rapp. P.-v. Cons. Int. Explor. Mer. 187, 98-102.

Tyrell, T., 2011. Quality-controlled datasets of coccolithophore distributions between UK and Spain. European Project on Ocean Acidification (EPOCA) document D3.7.

UK Met Office, 2010a. Data for Buoy 62001 in Bay of Biscay at 45.3N, 5.0W.

UK Met Office, 2010b. Data for Buoy 63201 in English Channel at 49.9N, 2.9W.

Varela, M., 1996. Phytoplankton ecology in the Bay of Biscay. Sci. Mar. 60, 45-53.

Vanhoutte-Brunier, A., Fernand, L., Ménesguen, A., Lyons, S., Francis Gohina, F., Cugiera, P., 2008. Modelling the Karenia Mikimotoi bloom that occurred in the western English Channel during summer 2003. Ecol. Modell. 210, 351-376.

Widdicombe, C.E., Eloire, D., Harbour, D., Harris, R.P., Somerfield, P.J., 2010. Longterm phytoplankton community dynamics in the Western English Channel. J. Plankton Res. 32, 643-655.

Wright, S.W., Jeffrey, S.W., 1987. Fucoxanthin pigment markers of marine phytoplankton analysed by HPLC and HPTLC. Mar. Ecol. Prog. Ser. 38, 259-266.

Yool, A., Martin, A.P., Fernández, C., Clark, D.R., 2007. The significance of nitrification for oceanic new production. Nature 447, 999-1002, http://dx.doi.org/10.1038/ nature05885.

Zapta, M., Jeffrey, S.W., Wright, S.W., Rodriguez, F., Garrido, J.L., Clemenston, L., 2004. Photosynthestic pigments in 37 species (65 strains) of haptophyta: implications for oceanography and chemotaxonomy. Mar. Ecol. Prog. Ser. 270, 83-102. 